\title{
CrimRxiv
}

\section{Crime Concentration and Temporal Stability in Spatial Patterns of Crime in Nis, Serbia}

Dušan Stanković ${ }^{1}$

${ }^{1} 0000-0002-2839-0536$

Published on: May 18, 2021

DOI: $10.21428 / \mathrm{cb} 6 \mathrm{ab} 371.460 \mathrm{fabd} 3$

License: Creative Commons Attribution 4.0 International License (CC-BY 4.0). 


\begin{abstract}
The research objectives were to examine the concentration of crime and its temporal patterns in Niš and compare the related research results in spatial criminology. Longitudinal property and violent crime data were geocoded and assigned to three types of grid cells. Descriptive statistics were used to examine crime concentration, and spatial stability of crime was tested using a spatial point pattern test. The findings suggest an intense concentration of all crime types within all areal units and years of study. The higher rates of concentration were found in the analysis of less common robbery and violent crime. Findings of spatial pattern analysis suggest moderate to a high degree of similarity in spatial patterns among all crime types. On the other hand, sensitivity analysis indicates significant changes in the spatial distribution of both property and violent crime. Therefore, an alternative method is applied. Theoretical implications are discussed, highlighting routine activities and crime pattern theory. The study aims to instigate more spatial analysis of crime and evidence-based criminal policies within the region.
\end{abstract}

Keywords Crime concentration; Spatial patterns; Property and Violent crime; Serbia

\title{
Introduction
}

The "law of crime concentration at places" is the first law of criminology of place (Weisburd, 2015). Many studies support the hypothesis that a crime is concentrated in particular places (Sherman, Gartin, Buerger, 1989; Eck, Clake, Guerette, 2007; Weisburd, Morris, Groff, 2009; Andresen, Curman, Linning, 2017; Hardyns, Snaphaan, Pauwels, 2019). Numerous studies have examined crime concentration and its spatial patterns, and although crime scientists are generally in agreement regarding crime concentration, the issue of the spatial stability of crime remains. The temporal stability in spatial patterns of crime may be defined as the maintenance of the places and trajectories where crime occurs less or more frequently throughout a particular period in time.

Findings are diversified among different studies, approving and declining the stability of spatial patterns of crime. Weisburd et al.'s (2009) longitudinal research of juvenile arrests in Seattle found that high rate juvenile crime street segments remained relatively stable across the studied period of 14 years. Andresen and Malleson's (2011) analysis found that general crime patterns are more similar in all areal units of Vancouver. Their sensitivity analysis suggested significant variations within larger 
spatial units. In the study of homicides in Recife (Brasil), Pereira, Mota, and Andresen (2016) partly declined spatial patterns' stability but found that crime was highly concentrated in the study area. In a longitudinal study on the stability of residential burglaries in Antwerp (Belgium), Vandeviver and Steenbeek (2017) indicate a moderate to a high degree of spatial stability over time. In total, they found that $91 \%$ of street segments with burglary experienced a net decrease, while only $1 \%$ experienced a net increase.

According to the described studies, spatial criminologists are interested in the spatial behaviour of various types of crimes in various places. Although crime as a social phenomenon is inconvenient to predict, environmental criminology implies that it could be predicted.

This study is built on the European and global foundations of spatial criminology. Although some studies have been conducted on the geography of crime in Serbia (Baić, Kolarević and Bojković, 2015; Milić, 2015; Milojković and Petrović, 2019; Stanković, 2021), either their data or methods do not concern the concentration and spatial patterns of crime. Thus, the objectives of this research are:

- To examine the concentration of property and violent crime in Niš, Serbia;

- To test similarities in spatial patterns of property and violent crime in Niš over time;

- To compare the results of the concentration and spatial patterns of property and violent crime with the results of the relative research;

- To introduce evidence-based policies from an aspect of spatial criminology and encourage future research in the field.

To meet these goals, property and violent crime data in Niš from 2008, 2013, and 2018 , were geocoded and assigned to the spatial units of analysis. The concentration of crime is examined using descriptive and inferential statistics. A nonparametric point pattern test is applied to examine the temporal stability of spatial patterns in crime. The results are discussed and compared to comparative studies of crime concentration and spatial patterns of crime in Europe and worldwide. Theoretical considerations and implications for further research and practical usage of the results are specified.

\section{Theoretical background}

Adolphe Quetelet, a Belgian mathematician and sociologist and founder of the cartographic school, analysed high-crime areas during the mid-19 ${ }^{\text {th }}$ century. His findings that crime is differently distributed in space are the first of their kind 
(Quetelet, 1842). The ecological theory of crime emerged in Chicago during the 20 ${ }^{\text {th }}$ century. In "Juvenile delinquency and urban areas" (1942), Shaw and McKay conclude that concentric circles that divide the city have various rates of crime and disorganisation. They suggest that crime is stable and that some areas have high crime rates, notwithstanding cultural changes in population and ethnicity. During the 1970s, a group of scholars began to develop theories that focus on why crime occurs in certain areas. The opportunity theories that they developed have been instrumental in guiding the investigation of place and crime (Groff, Weisburd, Yang, 2010, p. 9). Opportunity theories build upon the environment of crime, emphasising that specific circumstances are needed in order for a crime to thrive. Those include situations when the offender and victim's everyday activities intersect with a lack of guardianship in the current location. Cohen and Felson (1979) developed routine activity theory, which describes a triangle of crime: a motivated offender (lately called likely offender), an unprotected victim, and a suitable place. In Crime and Everyday Life, Felson (1986) adds another suppressor of crime: handlers, which refers to people in the life of an offender whose influence discourages or prevents them from committing a crime. Rational choice theory is based on the offender's notion of crime as a rational choice, as every offender's choice to commit a crime is based on its perceived costs and benefits (Cornish, Clarke, 1986). Finally, Brantingham and Brantingham $(1993,1995)$ developed the crime pattern theory based on environmental criminology principles. They identify four types of crime places: crime generators, crime attractors, crimeneutral places, and fear generators. Brantingham and Brantingham (1995) define crime generators as particular areas to which large numbers of people are attracted for reasons unrelated to any particular level of criminal motivation they might have or to any particular crime they might end up committing. Crime attractors are particular places, areas, neighbourhoods, or districts that create well-known criminal opportunities to which strongly motivated, intending criminal offenders are attracted due to the known opportunities for particular crime types (Brantingham and Brantingham, 1995: 8). These sites become activity nodes for repeat offenders who enter the area intending to commit a crime. In their retrospective on the geometry of crime and crime pattern, Brantingham, Brantingham, and Andresen (2017) conclude that crime is not randomly distributed through time and space. The cluster shape is greatly influenced by where people live; how and why they move; and how networks of people spend their time. There are concentrations of overlapping activity nodes, within which some situations become crime generators and others become crime attractors. Brantingham, Brantingham, and Andresen (2017) add that representation of crime locations should consider the following: individual offenders and their routine activity 
spaces; networks of friends who engage in crime and their joint activity spaces; the location of stationary targets and the activity spaces of mobile victims and mobile targets; and the catchment areas of fixed targets.

Sherman (1995, p. 36) defines a hotspot of crime as "small places in which the occurrence of crime is so frequent that it is highly predictable, at least over a one year period" and emphasises that it is distributed worldwide. Crime concentration studies have proven that crime is concentrated around particular places in urban areas, such as cities' business, shopping, and recreational areas. Sherman, Gartin, and Buerger (1989) conducted the first study of crime that identified high crime concentration. The most remarkable finding from this Minneapolis-based research is that $50 \%$ of police calls over one year originated from $3 \%$ of places. Subsequent studies confirmed this result and found that 1 to $5 \%$ of places produce about $50 \%$ of crime. $2 \%$ of street segments in Brooklyn Park accounted for 50\% of the crime over 15 years (Gill, Wooditch, Weisburd, 2016), while in a study of Belgium's cities, 50\% of crime was concentrated in 1.61 to $5.37 \%$ of places (Hardyns et al., 2019).

In Weisburd, Bushway, Lum, and Yang's (2004) study of crime trajectories in Seattle over a 14 -year period, they define $84 \%$ of the examined street segments as stable trajectories. This study implies that changes in the rate of incident reports over time suggest a kind of stability of the scale. Questioning the stability of crime concentration, the researchers found that even if crime concentration is significant at crime hot spots, there is little stability in such concentration across time. The study of spatial patterns of crime in Vancouver began with Andresen (2009) and continued with Andresen and Malleson's (2011) analyses of the stability of crime patterns over ten years. Their results prove the law of crime concentration theory; less than $1 \%$ of street segments accounted for $50 \%$ of robbery, while $8 \%$ of street segments accounted for $50 \%$ of burglary. The crime was highly concentrated overall. For example, in the robbery case, less than $1 \%$ of street segments accounted for $50 \%$ of crime. From the $1 \%$ and less that experienced robbery, about $15 \%$ accounted for $50 \%$ of all robberies throughout the year. The correlation analysis implies that street segments with high numbers of one crime type usually have high numbers of other crime types. The percentage of street segments that accounted for $50 \%$ of crime was stable over the studied period, allowing the researchers to interpret that the concentration of crime had increased (Andresen and Malleson, 2011, p. 66). Their non-sensitivity analysis (analysis with all the spatial units, regardless of whether any units experience no crime) found that crime is more stable at the street segments level (smaller units) than at the levels of census tracts and dissemination areas. Therefore, the authors conducted a sensitivity 
analysis, including only non-zero spatial units. However, the results of the sensitivity analysis did not significantly differ from the former. The Indices of Similarity decreased in general, but the pattern remained unchanged, and similarity was higher at smaller units of analysis. Another longitudinal study in Vancouver, which used only property crime data, found high similarities in street segments and intersections (Andresen et al., 2017).

Using a spatial point pattern test (SPPT), spatial stability of crime was analysed worldwide among various crimes. For example, in homicide analysis in Recife (Brasil), both global (analysis with all the areal units) and robust (sensitivity analysis with only non-zero event units) $S$ values were found to be significant (Pereira et al., 2016). Global $S$ values were between 0.977 and 0.978 (these indices represent high similarity) during the study years of 2009 to 2013; meanwhile, non-zero events street segments hit between 0.718 and 0.722 values, suggesting moderate to high similarity. At the census tract level, global values varied around 0.75 , while robust values exceeded 0.6. This finding may imply that more serious crime that occurs less frequently has more stable spatial patterns. Vandeviver and Steenbeek (2017) analysed residential burglary in Antwerp (Belgium) at the street segment level. Their findings suggest a high similarity in global analysis with all the indices above 0.90, from 2005 to 2016. However, when sensitivity analysis was applied with non-zero street segments, indices were much lower. The results varied from 0.33 to 0.42 . They also computed a multivariate robust global $S$-Index for non-zero event street segments, including all street segments that had at least one event throughout the 12-year study period. Findings were somewhere between global and robust analysis, with indices of about 0.70 .

As Andresen, Linning, and Malleson (2016) imply, "although a high degree of crime concentration implies that spatial stability is present, this may not be the case because there still may be enough spatial shifting in the other $50 \%$ of crime to cause problems for theory and policy." Therefore, scientific and practical reasons stand for the empirical research of spatial patterns of crime.

\section{Data and Methodology}

\section{Study Area and Crime Data}

The city of Niš is the third most populous city in the Republic of Serbia. According to data from the 2011 census, it has a population of 260,274 with 183,164 urban residents. With a size of 596.73 square kilometres (about 266 square kilometres of 
which is the urban zone), Niš is the largest city in central and southeastern Serbia. It is an administrative, legislative, business, university, and sports centre in this part of the country.

Crime data was obtained from the Police Department in Niš and consisted of property and violent crime committed on the urban territory of Niš in 2008, 2013, and 2018 calendar years. $\underline{1}$ Property crime data includes the following criminal offences from the Criminal Code of the Republic of Serbia: theft (Article 203), aggravated theft (Article 204), grand theft/larceny (Article 205), and robbery (Article 206). Violent crime data includes serious bodily injury (Article 121), minor bodily injury (Article 122), brawling (Article 123), threat or endangerment by dangerous instruments in brawl or quarrel (TIDBQ) (Article 124), and violent conduct (Article 344). These criminal offences were analysed following the literature review of similar studies (Weisburd et al., 2004; Andresen and Malleson, 2011a; Melo, Matias, Andresen, 2015). Some criminal offences that may be relevant were not required for the research. For example, violent acts like homicide and sexual acts are rare, and would thus be statistically irrelevant. The period of five years was considered to be an adequate framework. Firstly, this time span was used in the previous studies of crime concentration and spatial patterns of crime, in somewhat similar circumstances (Andresen and Malleson, 2011). Secondly, crime data of this kind is not freely available in Serbia. The data request had to be checked and evaluated by the Ministry of Interior before access was allowed. Finally, the data were processed in a manner that was adequate for the analysis of this research. The process of accessing crime data and processing the subsequent data for every year would demand further permissions and more time.

Due to small volumes of events (Table 1), the decision was to aggregate all violencemotivated criminal offences into a variable called "Violent crime". Additionally, grand theft/larceny was attached to robbery 2 due to its small counts. The aggregation was performed to achieve statistically relevant counts, while simultaneously ensuring that the individuality and nature of these criminal acts were not violated. In this case of aggregation, one may ask why theft and aggravated theft were not aggregated. Except for high volumes, this is because aggravated theft is an offence of theft committed by breaking into a property, and therefore more closely resembles a burglary in western crime classifications; this is the crucial difference from the aspect of spatial criminology.

Table 1 Descriptive statistics of Crime Data by Study Periods 


\begin{tabular}{|c|c|c|c|c|c|c|}
\hline & \multicolumn{2}{|c|}{2008} & \multicolumn{2}{|c|}{2013} & \multicolumn{2}{|c|}{2018} \\
\hline & Count & Percent & Count & Percent & Count & Percent \\
\hline Theft & 616 & 36.4 & 871 & 42.2 & 419 & 35.6 \\
\hline $\begin{array}{l}\text { Aggravat. } \\
\text { Theft }\end{array}$ & 832 & 49.2 & 1018 & 49.4 & 609 & 51.9 \\
\hline Robbery & 120 & 7.1 & 78 & 3.8 & 49 & 4.2 \\
\hline Grand Theft & 4 & 0.2 & 4 & 0.2 & 1 & 0.09 \\
\hline $\begin{array}{l}\text { Serious } \\
\text { Bod.Inj. }\end{array}$ & 19 & 1.1 & 22 & 1.1 & 25 & 2.1 \\
\hline $\begin{array}{l}\text { Minor Bod. } \\
\text { Inj. }\end{array}$ & 51 & 3.0 & 29 & 1.4 & 20 & 1.7 \\
\hline Brawling & 5 & 0.3 & 4 & 0.2 & 5 & 0.4 \\
\hline TIDBQ & 0 & 0.0 & 7 & 0.3 & 0 & 0.0 \\
\hline $\begin{array}{l}\text { Violent } \\
\text { conduct }\end{array}$ & 44 & 2.6 & 29 & 1.4 & 47 & 4.0 \\
\hline Total & 1691 & 100 & 2062 & 100 & 1175 & 100 \\
\hline
\end{tabular}

The final issue with this body of data was geocoding. Police provided the data with a number of particular criminal offences during one year in a particular address (street name and house number), without coordinates. Firstly, these numbers were divided into individual cases. Every particular event consisted of the street address where the crime took place. Next, the cases were geocoded automatically into $x$ and $y$ coordinates using Google Earth. Approximately 30\% of the cases were geocoded manually due to this software's inability to recognise addresses. $\underline{3}$ Additionally, cases whose address did not contain their house number were marked as "without number". $\underline{4}$ Geocoding would place these in the middle of the street and cluster multiple events at this point, regardless of whether they occurred on opposite sides of the street. This was particularly problematic for streets that were long enough to spread into more than one spatial unit. Therefore, these cases were divided equally among spatial units 
that overlay the street. The aim was to achieve the minimum acceptable hit (success) rate in spatial analysis. While Ratcliffe (2004) estimates this hit rate to be $85 \%$ in geospatial crime analysis, the latest research (Andresen, Malleson, Steenbeek, Townsley, and Vandeviver, 2020) found that it could be much lower. However, their results indicate successful lower rates when the number of events is higher than the spatial units of analysis. Since that was not the case in this study, the aim was to achieve $85 \%$ successful geocoding. Finally, 4,956 individual cases were extracted from the data. Of those, 4,928 events were successfully geocoded, producing a $99.4 \%$ success rate that was demonstrably higher than Ratcliffe's (2004) 85\%.

\section{Spatial Units of Analysis}

In previous studies on crime concentration and spatial patterns, researchers would often use spatial units such as census tracts (Andresen, 2009; Melo et al., 2015), dissemination areas (Andresen and Malleson, 2011; Boivin and Melo, 2019), and street segments (Weisburd et al., 2004; Vandeviver and Steenbeek, 2017). In the current case, the smallest administrative units were local communities, similar to North American census tracts. The data required for the analysis was not available, $\underline{5}$ and there were no smaller units appropriate for micro-level analysis. Therefore, raster grid cells were used as spatial units. These are often used in the spatial analysis of crime concentration (Hardyns et al., 2019) or its risk factors (Caplan, Kennedy, Miller, 2011; Barnum, Cambell, Trocchio, Caplan, Kennedy, 2017). One application of SPPT using the grid cells is known to the author, namely Wheeler, Steenbeek, and Andresen (2018), who used 500 by 500-metre grids in their analysis and concluded that it eliminates the problems of inconsistency between the two-point pattern geocoding and provides reasonably small areas. Some authors argue that it is important to consider grid cells as micro-level places for crime analysis as they can be seen as behavioural settings from a theoretical perspective (Hardyns et al., 2019, p. 13). Hardyns et al. (2019) add that from a methodological perspective, the street segment level might be less useful in European cities than in the US context due to their specific morphology (European cities are more similar geographically to nonmetropolitan US cities).

Given the potential for spatial bias, three types of grid cells were constructed for this study: 100 by 100,500 by 500 , and 1,000 by 1,000 metres. Every type of grid cell was created in accordance with previous research and spatial units, which were applied. Therefore, grid cells of 1,000 by 1,000 metres were used as the largest spatial units for analysis, similarly to census tracts in previous studies (Andresen and Malleson, 2013). 500 by 500 metres were used in the previous application of an alternative to 
Andersen's spatial point pattern test (A. Wheeler et al., 2018). Finally, 100 by 100 metres were used as smaller spatial units, similarly to street segments in spatial crime analysis (Melo et al., 2015; Weisburd et al., 2004, 2009). In total, there are: 90 cells of 1,000 by 1,000 ; 360 cells of 500 by 500 ; and 9,000 cells of 100 by 100 metres.

\section{Analytical Strategy}

Firstly, empirical research examined the concentration of crime at places using three types of spatial units. The analysis was conducted through the descriptive statistics used in crime concentration studies (Weisburd et al., 2004; Andresen et al., 2016; Weisburd, 2015). The results were presented by percentages of spatial units with any crime, percentages of spatial units that accounted for $50 \%$ of crime, and percentages of spatial units with crime accounting for $50 \%$ of crime (Table 2, Table 3, Table 4). Parametric and nonparametric correlation analysis was conducted to investigate the correlation between spatial units and their concentration (Table 5).

Secondly, Andresen's spatial point pattern test was applied (Andresen, 2009, 2016) to examine temporal stability in spatial patterns of crime. This test has been used in various studies of spatial patterns' similarities, mostly regarding criminological aspects (Andresen and Malleson, 2014; Hodgkinson, Andresen, 2019). The spatial point pattern test with a nonparametric Monte Carlo approach can identify the degree of similarity between two datasets (Pereira et al., 2016, p. 318). Andresen $(2009,2016)$ provides extensive description of the test and its previous application.

Briefly, SPPT examines the similarity between two georeferenced point-based data sets. One data set is used as a base data set, and the other as a test data set. According to Andresen (2016, p.3), "georeferencing is necessary because each point must be assigned to an individual areal unit of analysis. The spatial unit data may take any number of different forms of spatial units: a set of grids placed over the study area, neighbourhood boundaries, census tracts, or some other form of census boundary areas (census block groups, dissemination areas, output areas, etc.)". After assigning points, points within spatial units are counted, and the percentages of points within each are calculated. These percentages are compared between two data sets (base and test). This is the total amount of manipulation to be performed on the base data set. Turning only to the test data set, 85\% random sampling of the data should create an $85 \%$ confidence interval. Points should then be reassigned to the spatial units, prior to aggregation and calculation of the percentages. This process is to be repeated a number of times (the author of the test suggests 200). All percentages within each areal unit should be ranked, and a 95\% nonparametric confidence interval 
should be created by removing the top and bottom $2.5 \%$ of ranked percentages.

Finally, the areal unit is considered similar if the percentage of points for an areal unit in the base data set falls within the confidence interval of referenced areal units of the tested data set. This comparison will be made for all areal units. Vandeviver and Steenbeek (2017) describe it as "Local Similarity Indexes". These local S-Indices can be used for mapping the results and identifying and locating instances where the crime pattern has changed. Finally, Andresen $(2009,2016)$ calculates the global Index of Similarity, $S$, that ranges from 0 (no similarity) to 1 (perfect similarity). The formula is:

$$
S=\frac{\sum_{i=1}^{n} S_{i}}{n}
$$

Where $n$ is the number of areas, $S_{i}$ is equal to 1 if the spatial pattern neighbourhood sets are considered similar for the areal unit $i$, and 0 if it is considered dissimilar. The Index of Similarity represents the proportion of areal units in the test data set that are similar to areal units in the base data set. The S-Index threshold value for two data sets to be considered similar is 0.80 (Andresen 2009, 2016).

SPPT was applied using R programming language and SPPT functions available in $\mathrm{R}$ library (Steenbeek, Vandeviver, Andresen, Malleson, and Wheeler, 2018). In addition to the analysis of all the areal units, sensitivity analysis of non-zero event units was conducted, followed by a newly proposed alternative method proportion difference test (Steenbeek et al., 2018; Wheeler et al., 2018). Since many of the areal units of analysis contained zero events, the potential for spatial bias in the data was high. Therefore, the decision was to apply Wheeler et al's (2018) newly developed method, namely the proportion difference test. They constructed this direct test of the differences in the proportions instead of constructing a confidence interval around one pattern (Wheeler et al., 2018, p. 763). The aim was to overcome the weaknesses of the Monte Carlo approach of SPPT. For example, areas with zero events would always have from 0 to 0 per cent confidence interval. Therefore, if the area within the base data set were to have only one event, the local Index of Similarity would be 0 . This study used a simple chi-square approach with p-values adjusted for multiple comparisons using the false discovery rate (for more details: Steenbeek et al., 2018; Wheeler et al., 2018).

[CHART]

Figure 1 Niš Crime data by years of study

\section{Results}




\section{Crime Concentration in Niš}

Since there are no official crime statistics for Serbian cities, spatially oriented information about Serbian crime rates were obtained from the Statistical Office of the Republic of Serbia. The most measurable data involved adult perpetrators of crime in $2018, \underline{6}$ for which Niš is ranked third throughout Serbia in terms of the number of criminal charges submitted to public prosecutors. This information aligns with the status of Niš as the third-largest city in the country. Crime is generally unstable, increasing and decreasing over the study period (Figure 1). Total crime increased by $22 \%$ between 2008 to 2013, from 1,691 reported events to 2,062. In another five years, crime declined significantly to 1,175 criminal events (43\% decrease). Thus, crime fell by $30 \%$ from 2008 to 2018. Cases of theft and aggravated theft increased and decreased in correlation with this pattern. Theft increased by $41 \%$ from 616 events in 2008 to 871 events in 2013, after which it declined to 419 events in 2018 (48\%). The decrease in the theft was therefore larger than that of total crime (43\%). Aggravated theft also increased from 832 to 1,018 events in 2013 and decreased by $40 \%$ in 2018 to 609. On the other hand, robbery decreased throughout the entire study period. 124 events of robbery occurred in 2008, which decreased to 82 (for 34\%) in 2013 and 50 (40\%) in 2018. Violent crime decreased from 119 events in 2008 to 91 in 2013 and then increased to 97 events in 2018 (18\% overall decrease). The general trend of crime decreasing may be understood in the economic and political context. Firstly, the worldwide financial crisis that began in 2007 substantially impacted the Serbian economy in 2008. Antevski (2010) suggests that the main negative effects of the global economic crisis on the Serbian economy include, among others, the overall decline in production, decrease in the GDP (gross domestic product) growth rate, high unemployment rates, and growth in total debt. Previous crime studies imply that economic factors can affect crime rates (Andresen, 2015; Gould et al., 2002). For example, Edmark (2005) found that unemployment rates positively and significantly affected some property crimes. The unemployment rate in Serbia in 2008 was 13.71\%, $22.15 \%$ in 2013 , and $12.73 \%$ in 2018 , in a somewhat similar trend to that of the crime data. Secondly, the political situation in Serbia was turbulent from 2008 to 2018. In 2012, the government of Democrats was replaced by the Progressive party. The new party introduced new economic measures and social policies which may have had an impact on crime rates. It might be suggested that crime increased in 2013 due to this period of political turbulence, and subsequently decreased in 2018 as the government was established. Besides, crime rates are known to be dependent on policing priorities and practices, which are susceptible to possible manipulation for political purposes 
(Vand Dijk, in Philippe, 2009: 13). However, conclusions on these would require studies on this phenomenon, as changes in crime trends are slow and rarely a product of random shocks (Pyrooz et al., 2016).

Figure 2 shows a simple plotting of crime data in the 2018 year of study on the 500 by 500-metre grid cell. This type of spatial unit was presented for its medium-size grids. The map indicates that crime is concentrating and clustering, and that these crime clusters are in the centre of the city. For example, the most frequented grids in the centre of the map include crowded features like the central city square, promenades, shopping centres, the main bus station, and open markets. Outer parts of the city experience little to no crime. Besides the centre, crime clusters in the suburban area; settlements with a higher population; southern parts of the city; and industrial areas on the western and eastern sides. The spatial units where crime does not occur or rarely occurs are less populated areas, both ambiently and residentially. Crime occurs less frequently in the western and eastern parts of the city; these are suburban areas and newly built settlements, less populated than ones on the southern and southeast parts of the map. Furthermore, this area consists of industrial zones that were built during socialism but failed to survive the post-socialist transformation of 2000. Crime is especially rare on the southern area of the map, whose less populated suburban area contains many vacation houses and no business facilities.

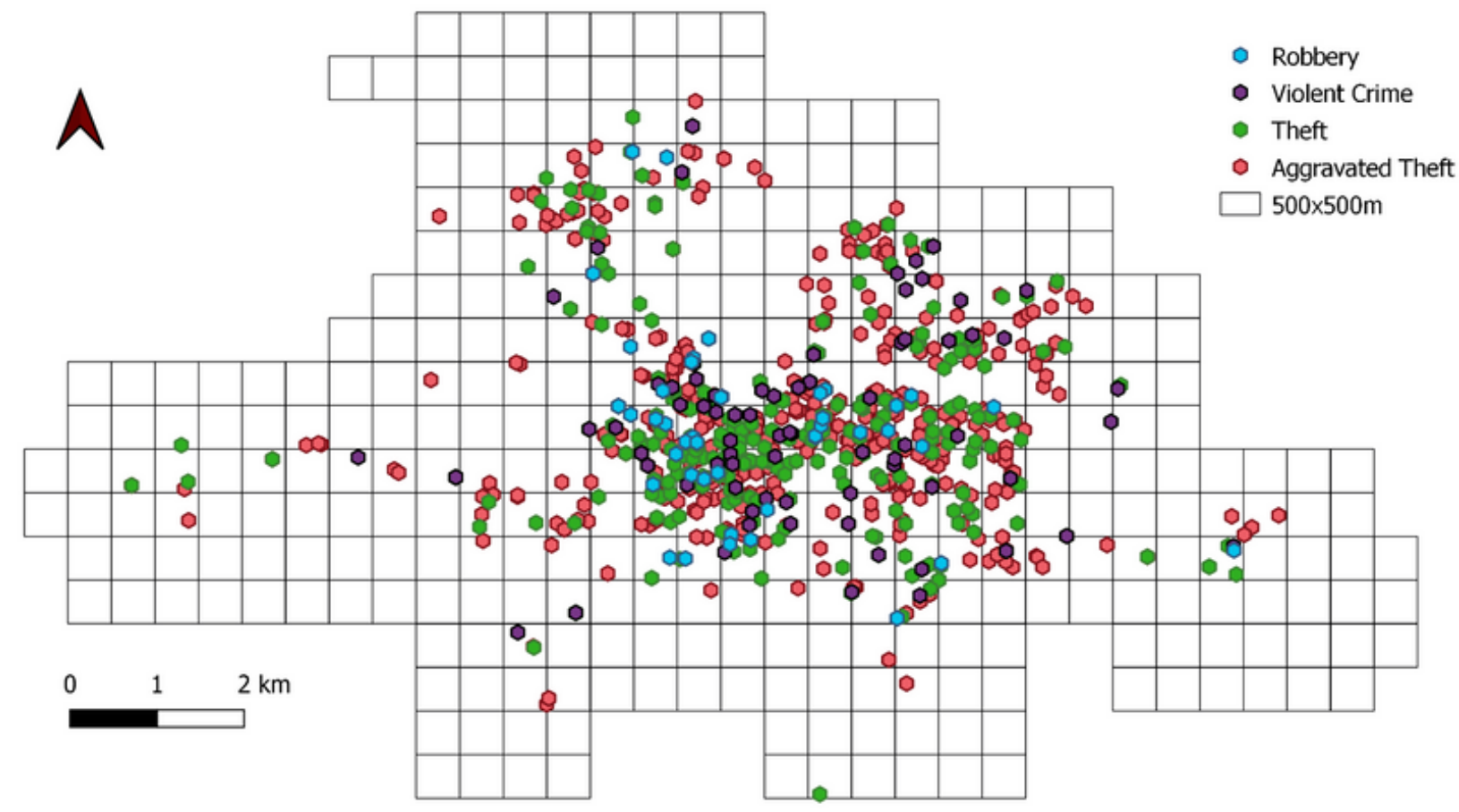


Figure 22018 crime point data in 500 by 500-metre grid cell

Crime concentrations are found in spatial units of analysis (Tables 2, 3, and 4). Table 2 outlines the percentages of spatial units that experienced at least one event by crime type. The highest concentrations are in 100 by 100 grid cells. Between 2.72 and $4.87 \%$ of spatial units experienced theft throughout the research periods. The remaining crime types follow this concentration. The results of aggravated theft suggest variation in its concentration that follows its frequency in studied years, counting 832, 1,018, and 609 events in 2008, 2013, and 2018, respectively. In 2008, 4.33\% of the smallest grid cells had any aggravated theft. This increased to 5.65\% in 2013 but dropped to $4.23 \%$ in 2018. A noticeable pattern is that crime is less concentrated within larger units of analysis. Robbery in 2018 (7.5\%) and violent crime in 2008 (7.75\%) were the most concentrated crimes in 500 by 500 -metre grids. 1,000 by 1,000-metre grid cells experienced the most crime. Theft and aggravated theft occurred within 46.64 and $60 \%$ of the largest spatial units, while robbery and violent crime occurred between 18.89 and $34.44 \%$. Within the larger unit of analysis, there is a noticeable chance for spatial units to experience increases in crime. Additionally, more frequent crime increases the possibility for all spatial units to experience it.

Table 2 Percentage of spatial units that experienced at least one crime

\begin{tabular}{|c|c|c|c|c|c|c|c|c|c|}
\hline & \multicolumn{3}{|c|}{2008} & \multicolumn{3}{|c|}{2013} & \multicolumn{3}{|c|}{2018} \\
\hline & $100 \mathrm{~m}$ & $500 \mathrm{~m}$ & $1000 \mathrm{~m}$ & $100 \mathrm{~m}$ & $500 \mathrm{~m}$ & $1000 \mathrm{~m}$ & $100 \mathrm{~m}$ & $500 \mathrm{~m}$ & $1000 \mathrm{~m}$ \\
\hline Theft & 3.08 & 26.11 & 47.78 & 4.87 & 33.33 & 56.67 & 2.72 & 27.22 & 47.78 \\
\hline $\begin{array}{l}\text { Aggrava } \\
\text { ted } \\
\text { theft }\end{array}$ & 4.33 & 28.61 & 46.67 & 5.65 & 34.44 & 60 & 4.23 & 33.61 & 55.55 \\
\hline Robbery & 1.11 & 14.17 & 30 & 0.81 & 11.11 & 24.44 & 0.44 & 7.5 & 18.89 \\
\hline $\begin{array}{l}\text { Violent } \\
\text { crime }\end{array}$ & 0.96 & 7.75 & 32.22 & 0.81 & 13.33 & 33.33 & 0.84 & 13.89 & 34.44 \\
\hline
\end{tabular}

Spatial units that account for $50 \%$ of crime comprised between 0.17 and $18.51 \%$ of all spatial units (Table 3 ). In 2018 , only $0.17 \%$ of robbery and $0.30 \%$ of violent crime in the smallest grid cells accounted for 50\% of crime. Again, concentration is higher in the years in which crime was less prevalent, like 2008 and 2018, and counts are higher 
within bigger spatial units in every period. Nevertheless, neither of the cases exceed $5 \%$ of all units. Robbery is again the most concentrated crime with few exceptions in 2008 and 2013 when violent crime is more concentrated at the smallest level.

Table 3 Percentage of spatial units accounting for 50 per cent of crime

\begin{tabular}{|l|l|l|l|l|l|l|l|l|l|l|l|}
\hline & \multicolumn{3}{|c|}{2008} & \multicolumn{3}{c}{2013} & \multicolumn{3}{c|}{2018} \\
\hline & $100 \mathrm{~m}$ & $500 \mathrm{~m}$ & $1000 \mathrm{~m}$ & $100 \mathrm{~m}$ & $500 \mathrm{~m}$ & $1000 \mathrm{~m}$ & $100 \mathrm{~m}$ & $500 \mathrm{~m}$ & $1000 \mathrm{~m}$ \\
\hline Theft & 0.31 & 3.33 & 5.55 & 0.77 & 5 & 7.78 & 0.53 & 4.17 & 6.67 \\
\hline $\begin{array}{l}\text { Aggrava } \\
\text { ted } \\
\text { theft }\end{array}$ & 0.79 & 3.33 & 5.55 & 1.16 & 5 & 6.67 & 0.98 & 5.83 & 8.88 \\
\hline \begin{tabular}{l} 
Robbery \\
\hline Violent
\end{tabular} & 0.42 & 3.61 & 5.55 & 0.34 & 2.78 & 4.44 & 0.17 & 2.22 & 4.44 \\
\hline crime & 0.30 & 3.89 & 6.66 & 0.31 & 3.61 & 5.55 & 0.30 & 3.33 & 6.66 \\
\hline
\end{tabular}

Only $10.71 \%$ of 100 by 100 grid cells that experienced theft in 2008 accounted for $50 \%$ of total theft in 2008 (Table 4). Except for this example, there is a stronger concentration within a larger unit. For example, in 2013, 43\% of 100 by 100 grid cells containing robbery events accounted for $50 \%$ of crime, compared with $21.9 \%$ in the 500 by 500 -metre grid cells and $18.18 \%$ in the 1,000 by 1,000 -metre analysis.

Table 4 Percentage of spatial units experiencing crime that accounts for 50 per cent of crime

\begin{tabular}{|c|c|c|c|c|c|c|c|c|c|}
\hline & \multicolumn{3}{|l|}{2008} & \multicolumn{3}{|l|}{2013} & \multicolumn{3}{|c|}{2018} \\
\hline & $100 \mathrm{~m}$ & $500 \mathrm{~m}$ & $1000 \mathrm{~m}$ & $100 \mathrm{~m}$ & $500 \mathrm{~m}$ & $1000 \mathrm{~m}$ & $100 \mathrm{~m}$ & $500 \mathrm{~m}$ & $1000 \mathrm{~m}$ \\
\hline Theft & 10.71 & 12.77 & 11.63 & 15.75 & 15 & 13.73 & 19.67 & 16.33 & 14.63 \\
\hline $\begin{array}{l}\text { Aggrava } \\
\text { ted } \\
\text { theft }\end{array}$ & 18.21 & 11.65 & 11.90 & 19.84 & 14.4 & 10.91 & 23.36 & 17.36 & 15.69 \\
\hline Robbery & 38 & 25.49 & 18.52 & 43 & 21.95 & 18.18 & 40 & 29.62 & 23.5 \\
\hline
\end{tabular}




\begin{tabular}{|l|l|l|l|l|l|l|l|l|l|}
$\begin{array}{l}\text { Violent } \\
\text { crime }\end{array}$ & 31.4 & 26.42 & 20.69 & 37.84 & 32.5 & 16.67 & 36.84 & 23.52 & 19.35 \\
\hline
\end{tabular}

Since crime is highly concentrated, the correlation was checked among crime types in 100 by 100 -metre grid cells. These are the smallest and most numerous spatial units, and the assumption that correlation would be even higher within bigger spatial units proved true. For example, the correlation between violent crime and aggravated theft in the 500 by 500 -metre grid cells was 0.58 and $0.50(p<.001)$. All crime types are positively and significantly correlated (Table 5). Most noticeable are the parametric and nonparametric correlation coefficients of theft and aggravated theft, which are above 0.50 . This higher correlation may be described as a consequence of higher numbers of events of these two crimes. Theft and aggravated theft are higher in volume than robbery and violent crime. From a qualitative perspective, it is also important to note that theft and aggravated theft are financially motivated. These crimes include motivated offender, suitable victim, and absence of guardianship. The strongest correlation coefficient is found between theft and violent crime in the parametric analysis, which may be explained through the ecological aspect of these crimes. Both theft and violent crime may occur in crowded places. For example, theft often occurs in locations with many potential victims, such as shopping malls, promenades, business centres. Similarly, assaults and fights often occur in places in which mass gatherings are typical, such as bars, restaurants, or sports events. In general, correlation analysis proved the assumption that spatial patterns of crime are similar regardless of their type.

Table 5 Correlation among crime types in 100 by 100-metre spatial units

\begin{tabular}{|l|l|l|l|l|}
\hline & Theft & Aggravated Theft & Robbery & Violent crime \\
\hline Theft & & 0.56 & 0.34 & 0.61 \\
\hline Aggravated theft & 0.54 & & 0.48 & 0.38 \\
\hline Robbery & 0.34 & 0.36 & & 0.25 \\
\hline Violent crime & 0.32 & 0.30 & 0.26 & \\
\hline
\end{tabular}

Kendall's (nonparametric) correlation coefficients are shown in the lower triangle, while Pearson's (parametric) correlation coefficients are shown in the upper triangle. All correlation significant at the level $\mathrm{p}<.001$. 


\section{Spatial Point Pattern Test application}

The pairwise application of the spatial point pattern test is shown in Tables 6, 7, and 8 . For every period of analysis, there are three different indices of similarity: Column GlobalS symbolises analysis with all the areal units, RobustS is for the analysis with non-zero areal units, and Diff symbolises the proportion difference test results.

Table 6 illustrates the results of SPPT, using 100 by 100 -metre grid cells as spatial units of analysis. In the second column, the results of SPPT global analysis (all areal units included) of 100 by 100 -metre grid cells are noticeably high. All global $S$-Indices are higher than the threshold value of 0.80 . On average, about $96 \%$ of 9,000 smallest grid cells of theft and aggravated theft analysis were spatially stable over five years. Within less frequent events of robbery and violent crime, even higher percentages (about 99) of areal units are similar. The results of global analysis within all the areal units suggest that crime is stable and similar. Regarding the sensitivity analysis of nonzero areal units, robust $S$ indices are lower, between 0.251 and 0.5 . The highest value is for violent crime in the pairwise analysis of 2013 and 2018, with an $S$-Index of 0.488. For violent crime, the noticeable pattern is that sensitivity analysis similarities are increasing throughout the study periods. In general, the results of the sensitivity analysis (areal units with events) suggest that there is no similarity, with more or less significance in the changes of spatial patterns of crime during the five-year period.

Table 6 SPPT results, 100 by 100-metre spatial units analysis

\begin{tabular}{|c|c|c|c|c|c|c|c|c|c|}
\hline & \multicolumn{3}{|c|}{$2008-2013$} & \multicolumn{3}{|c|}{$2008-2018$} & \multicolumn{3}{|c|}{ 2013-2018 } \\
\hline & GlobalS & RobustS & Diff & Globals & RobustS & Diff & GlobalS & RobustS & Diff \\
\hline Theft & 0.967 & 0.5 & 0.999 & 0.971 & 0.404 & 0.999 & 0.958 & 0.327 & 1 \\
\hline $\begin{array}{l}\text { Aggrava } \\
\text { ted } \\
\text { theft }\end{array}$ & 0.952 & 0.375 & 1 & 0.960 & 0.430 & 0.999 & 0.950 & 0.379 & 0.999 \\
\hline Robbery & 0.989 & 0.412 & 1 & 0.989 & 0.251 & 1 & 0.991 & 0.298 & 1 \\
\hline $\begin{array}{l}\text { Violent } \\
\text { crime }\end{array}$ & 0.990 & 0.409 & 1 & 0.990 & 0.442 & 1 & 0.992 & 0.488 & 1 \\
\hline
\end{tabular}


Indices of Similarity are lower in the next areal units of analysis, 500 by 500 metres (Table 7). In robbery and violent crime cases, they are still above 0.80 in the grid cells' global analysis. These results suggest that spatial patterns of crime are similar in every analysed period. On the other hand, indices are below the threshold values in all cases of theft and aggravated theft, indicating a high to moderate similarity. In a similar pattern to Table 6, less frequent crimes are reaching higher levels of similarity. Therefore, theft and aggravated theft hold between 73 and $76.9 \%$ similarity in 500 by 500 grid cells. Less common robbery and violent crime have between 87 and 90\% similar areal units throughout the global analysis periods. Again, sensitivity analysis results are far below the threshold value of $0.80 S$-Index, between 0.301 and 0.386 . The lowest and highest values of similarities are robbery in 2008-2013 and violent crime in 2013-2018. This pattern follows the one from the smallest grid level analysis. The results suggest that despite a moderate degree of similarity between spatial patterns, significant changes are happening in the spatial patterns of crime.

Table 7 SPPT results, 500 by 500-metre spatial units analysis

\begin{tabular}{|c|c|c|c|c|c|c|c|c|c|}
\hline & \multicolumn{3}{|c|}{$2008-2013$} & \multicolumn{3}{|c|}{ 2008-2018 } & \multicolumn{3}{|c|}{ 2013-2018 } \\
\hline & GlobalS & RobustS & Diff & GlobalS & RobustS & Diff & Globals & RobustS & Diff \\
\hline Theft & 0.747 & 0.310 & 0.994 & 0.769 & 0.308 & 0.997 & 0.752 & 0.340 & 1 \\
\hline $\begin{array}{l}\text { Aggrava } \\
\text { ted } \\
\text { theft }\end{array}$ & 0.747 & 0.325 & 1 & 0.738 & 0.313 & 0.991 & 0.730 & 0.340 & 0.991 \\
\hline Robbery & 0.877 & 0.301 & 1 & 0.883 & 0.322 & 1 & 0.908 & 0.312 & 1 \\
\hline $\begin{array}{l}\text { Violent } \\
\text { crime }\end{array}$ & 0.869 & 0.318 & 0.997 & 0.872 & 0.386 & 1 & 0.875 & 0.366 & 1 \\
\hline
\end{tabular}

The largest analysis unit, 1,000 by 1,000 metres, had the smallest similarities (Table 8). Global $S$ values are at the lowest level compared to global analysis with smaller spatial units. The most frequent, aggravated theft, again has the lowest global values. Sensitivity analysis follows its prior trend. Aggravated theft has the lowest level of stable areal units, $27.1 \%$ in $2008-2013$ comparison. The highest level of $41.1 \%$ stable areal units is in the 2008-2018 analysis of theft. Except for the case of robbery in the pairwise analysis of 2013 and 2018, the findings from both sensitivity and nonsensitivity analysis, spatial patterns of crime are not similar. 
Table 8 SPPT results, 1,000 by 1,000-metre spatial units analysis

\begin{tabular}{|c|c|c|c|c|c|c|c|c|c|}
\hline & \multicolumn{3}{|c|}{$2008-2013$} & \multicolumn{3}{|c|}{$2008-2018$} & \multicolumn{3}{|c|}{$2013-2018$} \\
\hline & Globals & RobustS & Diff & Globals & RobustS & Diff & Globals & RobustS & Diff \\
\hline Theft & 0.633 & 0.4 & 0.977 & 0.666 & 0.411 & 0.988 & 0.555 & 0.272 & 1 \\
\hline $\begin{array}{l}\text { Aggrava } \\
\text { ted } \\
\text { Theft }\end{array}$ & 0.522 & 0.271 & 1 & 0.555 & 0.259 & 0.966 & 0.533 & 0.288 & 0.966 \\
\hline Robbery & 0.788 & 0.406 & 1 & 0.744 & 0.281 & 0.988 & 0.8 & 0.307 & 1 \\
\hline $\begin{array}{l}\text { Violent } \\
\text { Crime }\end{array}$ & 0.766 & 0.4 & 1 & 0.744 & 0.394 & 1 & 0.711 & 0.315 & 1 \\
\hline
\end{tabular}

The third columns in Tables 6, 7, and 8 show the similarity of an alternative to standard SPPT, the proportion difference test (Wheeler et al., 2018). The differences in the results of this approach, compared to global and robust values, are evident. Indices of Similarity are hitting the maximum value of 1 in more than half of the cases. Precisely, in 22 of 36 (or $61.1 \%$ ) of the test results show the perfect spatial similarity between patterns of a particular crime in the five-year period. In other cases, the values are almost one and vary between 96.6 and $99.9 \%$ of stable spatial units. The pattern of these indices follows the pattern of global and robust $S$-Index in almost every case. Therefore, the lowest values are found in lower global and robust values, like aggravated theft analysis of 1,000 by 1,000-metre areal units. This does not follow the pattern of aggravated theft in the first period of comparison between 2008 and 2013. It is difficult to conclude a pattern in the proportion difference test, since the indices' differences are almost unnoticeable. However, it may be implied that the values more occasionally represent the perfect similarity in the analysis of robbery and violent crime, which follows the pattern of sensitivity and non-sensitivity analysis. According to this approach, spatial patterns of crime are similar and changes are minor. 


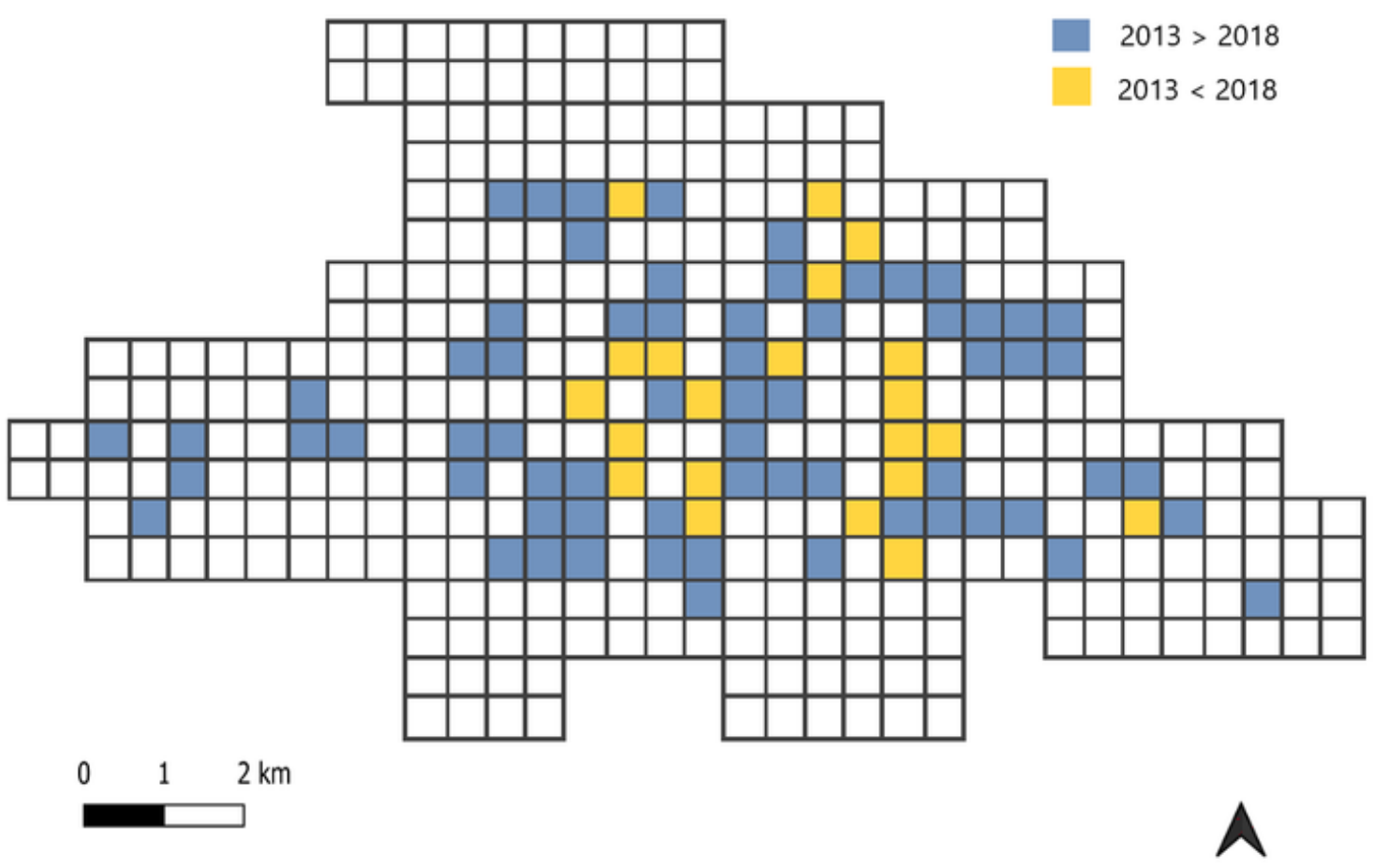

Figure 3 Theft differences between 2013 and 2018 in spatial units of 500 by 500 metres

To address spatial changes in crime, Figure 3 visually presents the results of the SPPT among thefts, again at the medium-sized spatial units. Since it could not be possible to visualise all the tests' results, theft is selected because it is spread across the map. Cases of theft have also declined significantly in recent years, from 871 in 2013 to 419 in 2018. Therefore, most of the cells had a significant decline. Nevertheless, some parts of the city are experiencing increases; mostly in the city's centre, in the eastern and southeastern urban settlements (e. g. newly built environment along the streets of Somborska, Borska).

\section{Discussion and Conclusion}

This study tested the law of crime concentration and temporal stability in spatial patterns of crime in Niš. The crime concentration results are in line with previous criminological research (Andresen and Malleson, 2011; Sherman, 1989; Weisburd et al., 2004). Crime concentration in 100 by 100 metres and 500 by 500 metres could be compared to Sherman (1989) or Weisburd's results (2015). On the other hand, Andresen and Malleson's (2011) results of Vancouver concentration indicate less concentration of crime than was found in this research. However, their analysis is 
based only on the street segment level. It may be implied that street segments in the North American context are similar to the current study's largest analysis units. Despite these differences, their less frequent crime types also tend to be more concentrated than others, like robbery and violent crime in this research.

The results are also in line with the recent analyses in Europe. Favarin's (2018) study of crime in Milan (Italy) suggests that 3.6 to $8.2 \%$ of street segments account for 50\% of burglaries. As discussed, current research tends to compare aggravated theft (as an act of break and enter) to burglary. Since street segments may vary from a few metres to hundreds, they can be compared with 100 by 100-metre grid cells. The current study's results in 100 by 100 metres suggest that only $0.79 \%$ of cells accounted for $50 \%$ of aggravated theft in $2008,1.16 \%$ in 2013 , and $0.98 \%$ in 2018 , similarly to Favarin's study. The results in 500 by 500 metres also suggest strong concentration, with between 3.33 and $5.83 \%$ grids accounting for $50 \%$ of robbery. In another study of burglary (Vandeviver and Steenbeek, 2017), about 2\% of street segments are responsible for $50 \%$ of all residential burglaries in Antwerp, while $9 \%$ of street segments experienced this crime. Their results varied from $2.55 \%$ of street segments responsible for 50\% burglary in 2005 to $1.83 \%$ in 2016 . These are in line with results of 500 by 500 grid cells accounting for $50 \%$ of aggravated theft (percentages are between 1.75 and $3.1 \%)$.

Similarly to some other studies (Andresen and Malleson, 2011; Melo et al., 2015), the most concentrated crime in the current study is robbery. Andresen and Malleson (2011) found concentration from 0.09 to 3.66\% of street segments accounting for $50 \%$ of crime. This is similar to the current study's results, in which between 0.17 and $0.98 \%$ of 100 by 100 -metre cells account for $50 \%$ of crime. Hardyns et al.'s (2019) research on three Belgian cities found that about $2 \%$ of 200 by 200 grid cells account for $50 \%$ of aggravated robbery, and more dispersed, about $5 \%$ for residential burglary. Counts in 100 by 100 and 500 by 500-metre grid cells for robbery and aggravated theft suggest almost the same levels of concentration (Table 4). Additionally, Hardyns et al. (2019) found that about 3\% of grid cells accounted for $50 \%$ of assault and battery crime. The current study's violent crime results varied from $0.30 \%$ in the smallest unit in 2008 to $6.66 \%$ in 1,000 by 1,000-metre grid cells in 2008 and 2018, indicating similar concentration.

The results indicate that violent crime (including robbery) is more concentrated than property crime (Tables 2, 3, and 4), similarly to the results found in previous criminological research worldwide (Lee et al., 2017; Favarin, 2018). Noticeable are the 
lower frequencies of violent crime in this study, as in those mentioned; therefore, the phenomenon of less common crime tending to be more concentrated should be investigated in the future. Weisburd's (2015) study of a similarly populated city (Cincinnati) found that $50 \%$ of crime concentrates at $6 \%$ of street segments. This study's results can be compared to the results of the 500 by 500 metres spatial unit analysis, as similar units to North American street segments. Although results in this analysis vary, they are $3.32 \%$ on average, suggesting stronger concentration. This premise should be taken with caution since the spatial units of analysis differ in this study compared to others.

To test the stability of crime patterns, SPPT was applied. The results of the test varied depending on the spatial unit of analysis. The highest similarities were found in the smallest areal units (Table 6). The global analysis resulted in Indices of Similarity higher than 0.95 across every study period and every type of crime. Antwerp's analysis of residential burglary (Vandeviver and Steenbeek, 2017) found global $S$ values above 0.90. In the current study, a similar crime type - aggravated theft - reached the same values. On the other hand, in the first analysis of this kind, Andresen and Malleson (2011) found similarities between 0.408 and 0.941 . They also found a more substantial similarity in less frequent crimes such as sexual assault and robbery, the same as the current study. In general, the results of the global analysis of the smallest units suggest similarities among all study periods in all types of crime. Within larger units of analysis, the indices are lower. The medium grid cells of 500 by 500 metres (Table 7) vary around the threshold value of similarity, but at the biggest units of 1,000 by 1,000 metres (Table 8), they do not reach this value. Similar results are found in other studies (Andresen and Malleson, 2011, 2013).

Using only spatial units that had crime, robust $S$ indices differed from global $S$ values. They suggested no to moderate similarity in spatial patterns of crime, dependent on the spatial units of analysis. The results indicate that theft and aggravated theft are experiencing the most noticeable changes, which aligns with the previous findings of theft and burglary (Andresen and Malleson 2011). On the other hand, Andresen et al.'s (2016) temporal analysis of commercial burglary, theft of vehicle, and theft from the vehicle produced higher robust $S$ indices and minor differences in sensitivity and nonsensitivity analysis. However, periods of analysis in their study are year by year, unlike the current study. The broader period between data sets may be the reason for more significant robust values. 
Since the results of non-sensitivity and sensitivity analysis were not adequate for a conclusion, the decision was to implement an alternative method to SPPT that excludes its shortcomings regarding the high number of zero event units in analysis. This also contributes to the methodological importance of the research, as it is one of the first SPPT applications using the proportion difference test known to the author. The higher indices are found across all study periods and all crime types. The test indicated a high similarity of spatial patterns of all crimes in every analysed period. However, the results of the SPPT Monte Carlo approach could not be excluded from the conclusion. Analysis of all the smallest and medium grids cells resulted in moderate and high similarities. Among larger units of analysis, similarity indices were declining. This analysis resulted in moderate to no similarities and suggested changes in the spatial patterns of crime. Therefore, it can be implied that while spatial patterns of crime in Niš are moderate to similar, they are experiencing changes, especially in more frequent and dispersed crime types. The most substantial values of similarity are found in robbery and violent crime analyses. Crime concentration and similarity in spatial patterns of robbery and violent crime are more significant than in aggravated theft and theft.

It can be concluded that crime is concentrated and generally stable in space. The results support the implications from a theoretical background in spatial criminology (routine activities, rational choice, the geometry of crime, and crime pattern theory). The crime is concentrated in the most crowded areas in the city, whose high ambient populations attract offenders and create crime opportunities. This kind of convergence of motivated (likely) offender, suitable target (victim), and absence of guardianship highlights the Routine activity theory. The spatial units that frequently experience crime include many opportunities, like retail shops, shopping centres, and open markets. Offenders compare the benefits and costs of the action, making a rational choice to act and escape. Other parts of the city that include residential areas and exindustrial zones are less attractive for offenders, producing a lower number of crimes. These implications should be analysed further in research on the micro place.

It can be suggested that crime concentrates on people's standard routes, working, occupational and entertainment environments. The high crime grid cells represent the city's central area in 2018 (Figure 2), and this spatial pattern is generally stable throughout the study period (Tables $6,7,8$ ). It includes the central city's square, main promenades, shopping centres, and business centres. The geometry of crime (Brantingham, Brantingham, and Andresen, 2017) comprises backcloths composed of social, economic, political, and physical dimensions. These dimensions gain people's 
activity nodes and create their movement patterns. At its northern part, across the bridge, the central square merges with two more nodes. One street includes a few open markets, many retail shops, and the main bus station. The other pathway from the fortress includes a large park; a few cafes and restaurants; and cultural and monumental objects like galleries and museums. This urban structure of the area evokes thoughts from crime pattern theory and the geometric theory of crime (Brantingham et al., 2017). It creates pathways and nodes in terms of crime geometry that suggest criminals are likely to commit their initial crimes near learned paths and activity nodes, or their friendship network. It is implied that crimes are likely to cluster near these activity spaces, with a higher concentration near the activity nodes (Brantingham et al., 2017). Since the current study did not comprise timely oriented data; pathways of victims and offenders; nor awareness spaces of offenders, these assumptions should be deployed in another study. To conclude, there are noticeable theoretical considerations, particularly in the context of the routine activities theory and crime pattern theory.

The study's findings are valuable for criminal policies in the region, particularly police agencies' crime prevention strategies. The results suggest that crime is concentrated and generally stable in its spatial patterns. Therefore, particular areas that produce much of the crime should be targeted (Figure 2), and it may be expected that interventions would not diffuse crime further. Places that should be targeted have narrowed in recent years due to the $30 \%$ overall decrease in crime, and the concentration of crime has increased in some spatial units from 2013 to 2018. This recommendation applies particularly to robbery and violent crimes, which have become more concentrated and similarly distributed in space over the years. Places that create opportunities for crimes in the central business area, and those that converge likely offenders and suitable targets with an absence of capable guardianship, should be targeted by the police. The study may bring some policy recommendations for local authorities in urban design. There has been some effort in towards urban development in Niš that would be beneficial for crime reduction. For example, urban plans anticipate displacement of the main bus station and market places in the Djuka Dinic, the street that merges with the central square and fortress. This kind of displacement would interrupt learned pathways for offenders and victims and restrict offenders' awareness space, thereby promoting crime reduction. On the other hand, rumours place markets in the area known as "Dark road"; this area is presented by grid cells that experienced increased crime from 2013 to 2018 on the central left of Figure 3. This kind of urban design may result in crime displacement 
and the creation of new nodes and pathways. Therefore, urban planning projects should include criminologists or at least some representatives from law enforcement. Furthermore, Figure 3 presents the differences in crime on 500 by 500 metres between 2013 and 2018. Although they are exceptions, particular cells in the central, eastern, and northeastern parts of the city are experiencing increases in crime that should be targeted by a police car and foot patrols. Situational prevention of crime has previously been criticised with the suggestion that it merely moves a crime around the corner and diffuses it. However, recent studies find that geographically focused policing initiatives were associated with reductions in crime and disorder (Bowers et al., 2011) and even diffused crime control benefits to nearby areas (Weisburd et al., 2006; Bowers et al., 2011). Therefore, the greatest potential of the current study lies in the situational prevention of crime.

It is necessary to address this study's limitations. Firstly, there are some issues with crime data. Police statistics include only reported events, and it can be assumed that the true number of occurrences is considerably larger. $\underline{7}$ Next, it had to be adjusted to the purposes of the research, in terms of the necessary geocoding. This process increases the potential for error, making it the researcher's responsibility to avoid georeferencing errors wherever possible until police data in Serbia become georeferenced. Secondly, no standardised spatial units were available in Serbia that were appropriate for this study. There were no administrative-boundary units needed for micro-level analysis, and the only territorial boundary unit was not available for the research. The modifiable areal unit problem (Andresen, 2016, p. 5) was present in this research, reflecting on the results. They changed dependently on a spatial unit of analysis. Although there were some issues regarding their suitable sizes, three different grid cells were designed to overcome spatial biases. The methods used in this research had certain weaknesses that resulted in the spatial biases and differences in values of similarities. However, the results were stable, and values followed each other's trends. As Andresen and Malleson (2013) conclude, similarities in spatial patterns of crime are dependent on the time period. In their research, ten years of Vancouver data produced significantly smaller indices of similarity than three years of Leeds data (Andresen and Malleson, 2013). Therefore, the suggestion is to use a shorter analysis period in future. Finally, the results should be taken with caution regarding both crime concentration and the stability of spatial patterns of crime. This study's results should be extended and tested within the region.

The study aimed to examine the law of crime concentration and temporal stability in spatial patterns of crime in Niš. It could be said that this aim was reached partially. 
Future research is needed for the confirmation of temporal stability in spatial patterns of crime. This study aims to encourage other spatial research and evidence-based practices of crime prevention in Niš and Serbia. The author considers these principles essential for criminal policy and law enforcement. Moreover, most importantly, the further development of criminology in this region depends on it.

\section{Declaration of Conflicting Interests}

The author declares no potential conflicts of interest with respect to the research, authorship, and/or publication of this article.

\section{Funding}

The author received no financial support for the research, authorship, and/or publication of this article.

\section{References}

Andresen, M. A. (2009). Testing for similarity in area-based spatial patterns: A nonparametric Monte Carlo approach. Applied Geography, 29(3), 333-345. https://doi.org/10.1016/j.apgeog.2008.12.004

Andresen, M. A. (2015). Unemployment, GDP, and Crime: The Importance of Multiple Measurements of the Economy. Canadian Journal of Criminology and Criminal Justice, 57(1), 35-58. DOI: 10.3138/CJCCJ.2013.E37

Andresen, M. A. (2016). An area-based nonparametric spatial point pattern test: The test, its applications, and the future. Methodological Innovations, 9(1-11). https://doi.org/10.1177/2059799116630659

Andresen, M. A., Curman, A. S., \& Linning, S. J. (2017). The Trajectories of Crime at Places: Understanding the Patterns of Disaggregated Crime Types. Journal of Quantitative Criminology, 33(3), 427-449. https://doi.org/10.1007/s10940-016-9301-1

Andresen, M. A., Linning, S. J., \& Malleson, N. (2016). Crime at Places and Spatial Concentrations: Exploring the Spatial Stability of Property Crime in Vancouver BC. Journal of Quantitative Criminology. https://doi.org/10.1007/s10940-016-9295-8

Andresen, M. A., \& Malleson, N. (2011). Testing the stability of crime patterns: Implications for theory and policy. Journal of Research in Crime and Delinquency, 48(1), 58-82. https://doi.org/10.1177/0022427810384136 
Andresen, M. A., \& Malleson, N. (2013). Spatial Heterogeneity in Crime Analysis. In Leitner, M. (ed.), Crime Modeling and Mapping Using Geospatial Technologies (3-23). https://doi.org/10.1007/978-94-007-4997-9

Andresen, M. A., \& Malleson, N. (2014). Police Foot Patrol and Crime Displacement: A Local Analysis. Journal of Contemporary Criminal Justice, 30(2), 186-199. https://doi.org/10.1177/1043986214525076

Andresen, M. A., Malleson, N., Steenbeek, W., Townsley, M., \& Vandeviver, C. (2020). Minimum geocoding match rates: an international study of the impact of data and areal unit sizes. International Journal of Geographical Information Science, 34(7), 117. https://doi.org/10.1080/13658816.2020.1725015

Antevski, M. (2010). Svetska ekonomska kriza i njen uticaj na privredu Srbije. Ekonomski horizonti, 12(1), 47-62.

Baić, V., Kolarević, D., \& Gojković, V. (2015). Prostorno-vremenske karakteristike krivičnog dela silovanja. In Lj. Mašković (ur.), Kriminalističko-forenzička obrada mesta krivičnih događaja, 2, 37-46.

Barnum, J. D., Campbell, W. L., Trocchio, S., Caplan, J. M., \& Kennedy, L. W. (2017). Examining the Environmental Characteristics of Drug Dealing Locations. Crime and Delinquency, 63(13), 1731-1756. https://doi.org/10.1177/0011128716649735

Boivin, R., \& Melo, S. N. (2019). Comparing global spatial patterns of crime. Policing: An International Journal, 42(6), 1097-1106. https://doi.org/10.1108/PIJPSM-05-2019$\underline{0073}$

Bowers, K., Johnson, S., Guerette, R. T., Summers, L., \& Poynton, S. (2011). Spatial displacement and diffusion of benefits among geographically focused policing initiatives. Cambell Systematic Reviews 2011.3 DOI: 10.4073/CSR.2011.3

Brantingham, P., \& Brantingham, P. (1995). Criminality of place - Crime generators and crime attractors. European Journal on Criminal Policy and Research, 3(3), 5-26. https://doi.org/10.1007/BF02242925

Brantingham, P. L., \& Brantingham, P. J. (1993). Nodes, Paths and Edges: Considerations on the Complexity of Crime and the Physical Environment. Journal of Environmental Management, 13, 3-28. 
Brantingham, P. L., Brantingham, P. J., \& Andresen, M. A. (2017). The geometry of crime and crime pattern theory. In R. Wortley and M. Townsley (eds.) Environmental Criminology and Crime Analysis. London and New York: Routledge. 98-116.

Caplan, J. M., Kennedy, L. W., \& Miller, J. (2011). Risk Terrain Modeling: Brokering Criminological Theory and GIS Methods for Crime Forecasting. Justice Quarterly, 28(2), 360-381. https://doi.org/10.1080/07418825.2010.486037

Cohen, L. E., \& Felson, M. (1979). Social Change and Crime Rate Trends: A Routine Activity Approach. American Sociological Review, 44, 588-605.

Cornish, D., \& Clarke, R. (1986). The Reasoning Criminal: Rational Choice Perspectives on Offending. New Jersey: Transaction Publishers.

Criminal Code of the Republic of Serbia (Official Gazette of RS, Nos. 85/2005, 88/2005, 107/2005). Source: Organization for Security and Co-operation in Europe. https://www.osce.org/serbia/18244?download=true accessed 01.04.2020.

Eck, J. E., Clarke, R. V., \& Guerette, R. T. (2007). Risky Facilities: Crime Concentration in Homogeneous Sets of Establishments and Facilities. Imagination for Crime Prevention: Essays In Honour of Ken Pease, 21(2007), 225-264.

Edmark, K. (2005). Unemployment and Crime: Is There a Connection? Scandinavian Journal of Economics, 107(2), 353-373. https://doi.org/10.1111/j.1467$\underline{9442.2005 .00412 . \mathrm{x}}$

Favarin, S. (2018). This must be the place (to commit a crime). Testing the law of crime concentration in Milan, Italy. European Journal of Criminology, 15(6), 702-729. https://doi.org/10.1177/1477370818757700

Felson, M. (2011). Crime and everyday life - Insights and Implications for society. Belgrade: Faculty of Law of the University of Belgrade.

Gill, C., Wooditch, A., \& Weisburd, D. (2016). Testing the "Law of Crime Concentration at Place" in a Suburban Setting : Implications for Research and Practice. Journal of Quantitative Criminology, 33, 519-545. https://doi.org/10.1007/s10940-016-9304-y.

Gould, E. D., Weinberg, B. A., \& Mustard, B. D. (2006). Crime Rates and Local Labor Market Opportunities in the United States: 1979-1997. The Review of Economics and Statistics, 84 (1), 45-61. 
Groff, E. R., Weisburd, D., \& Yang, S. M. (2010). Is it important to examine crime trends at a local "micro" level?: A longitudinal analysis of street to street variability in crime trajectories. Journal of Quantitative Criminology, 26(1), 7-32. https://doi.org/10.1007/s10940-009-9081-y

Hardyns, W., Snaphaan, T., \& Pauwels, L. J. R. (2019). Crime concentrations and micro places: An empirical test of the "law of crime concentration at places" in Belgium. Australian and New Zealand Journal of Criminology, 52(3), 390-410. https://doi.org/10.1177/0004865818807243

Hodgkinson, T., \& Andresen, M. A. (2019). Understanding the Spatial Patterns of Police Activity and Mental Health in a Canadian City. Journal of Contemporary Criminal Justice, 35(2), 221-240. https://doi.org/10.1177/1043986219842014

Lee, Y. J., Eck, J. E., SooHyun, O., \& Martinez, N. N. (2017). How concentrated is crime at places? A systematic review from 1970 to 2015. Crime Science, 6(1). https://doi.org/10.1186/s40163-017-0069-x

Милић, Н. (2015). Неке могућности анализе геопросторне дистрибуције кривичних дела у раду полиције. НБП - Журнал за криминалистику и право, 20(I), 99-117.

Melo, S. N., Matias, L. F., \& Andresen, M. A. (2015). Crime concentrations and similarities in spatial crime patterns in a Brazilian context. Applied Geography, 62, 314324. https://doi.org/10.1016/j.apgeog.2015.05.012

Milojković, B., \& Petrović, J. M. (2019). Geo-spatial and time distribution of criminal offenses in the Zrenjanin police office 2009-2018. Bezbednost, 61(3), 5-31.

Official website of the City of Nis, https://www.ni.rs/ accessed 05.04.2020.

Pereira, D. V. S., Mota, C. M. M., \& Andresen, M. A. (2016). The Homicide Drop in Recife, Brazil : A Study of Crime Concentrations and Spatial Patterns. Homicide Studies, 21, 1-18. https://doi.org/10.1177/1088767916634405

Pyrooz, C. D., Decker, H. D., Wolfe, E.S., \& Shjarback, A. J. (2016). Was there a Ferguson Effect on crime rates in large U.S. cities?. Journal of Criminal Justice, 46, 1-8. https://doi.org/10.1016/j.ssresearch.2012.05.013

Quetelet, A. (1842). A treatise on man and the development of his faculties. Edinburgh: W. and R. Chambers. 
Ratcliffe, J. H. (2004). Geocoding crime and a first estimate of a minimum acceptable hit rate. International Journal of Geographical Information Science, 18(1), 61-72. https://doi.org/10.1080/13658810310001596076

Shaw, C. R., \& MacKay, H. D. (1942). Juvenile Delinquency and Urban Areas: A Study of Rates of Delinquents in Relation to Differential Characteristics of Local Communities in American Cities. Chicago, IL: University of Chicago Press.

Sherman, L. W. (1995). Hot Spots of Crime and Criminal Careers of Places. Crime and Place, 4, 35-52.

Sherman, L. W., Gartin, P. R., \& Buerger, M. E. (1989). Hot Spots of Predatory Crime: Routine Activities and the Criminology of Place. Criminology, 27(1), 27-56. https://doi.org/10.1111/j.1745-9125.1989.tb00862.x

Stanković, D. (2021). Crime and environment: Analysis of facilities as crime risk factors in Niš, Serbia. Archives of Criminology, 17(2), 49-65. https://doi.org/10.7420/AK2020W

Statistic Office of the Republic of Serbia (2020). Adult Perpetrators of Crime, 2018. Belgrade. https://www.stat.gov.rs/en-US/publikacije/publication/?p=12218. Accessed 24.06.2020.

Statista.com - unemployment rate in Serbia. https://www.statista.com/statistics/440532/unemployment-rate-in-serbia/. Accessed 13.12.2020

Steenbeek, W., Vandeviver, C., Andresen, M. A., Malleson, N., \& Wheeler, A. (2018). sppt: Spatial Point Pattern Test. R package version (0.2.1). https://github.com/wsteenbeek/sppt. Accessed 08.04.2020.

Vandeviver, C., \& Steenbeek, W. (2019). The (In)Stability of Residential Burglary Patterns on Street Segments: The Case of Antwerp, Belgium 2005-2016. Journal of Quantitative Criminology, 35(1), 111-133. https://doi.org/10.1007/s10940-017-9371-8

Van Dijk, J. (2009). 'Approximating the truth about crime. Comparing crime data based on general population surveys with police figures of recorded crimes'. In Philippe, R. (ed.) Comparing crime data in Europe: official crime statistics and survey-based data. Brussels: VUBPress, 13-51.

Weisburd, D. (2015). The Law of Crime Concentration and the Criminology of Place. Criminology, 53(2), 133-157. 
Weisburd, D., Bushway, S., Lum, C., \& Yang, S.-M. (2005). Trajectories of Crime at Places: A Longitudinal Study of Street Segments in the City of Seattle. Criminology, 42(2), 443-476. https://doi.org/10.4324/9781315089256-19

Weisburd, D., Morris, N. A., \& Groff, E. R. (2009). Hot spots of juvenile crime: A longitudinal study of arrest incidents at street segments in Seattle, Washington. Journal of Quantitative Criminology, 25(4), 443-467. https://doi.org/10.1007/s10940009-9075-9

Weisburd, D., Wyckoff, L. A., Ready, J., Eck, J. E., Hinkle, J. C., \& Gajewski, F. (2006). Does crime just move around the corner? A controlled study of spatial displacement and diffusion of crime control benefits. Criminology, 44(3), 549-592.

Wheeler, A. P., Steenbeek, W., \& Andresen, M.A. (2018). Testing for similarity in areabased spatial patterns: Alternative methods to Andresen's spatial point pattern test. Transactions in GIS, 22(3), 760-774. https://doi.org/10.1111/tgis.12341

\section{Footnotes}

1. It should be noted that these police data include only criminal acts investigated by police and public attornies, not all reported events. Since there are no available data of all the reports, the assumption is that crime numbers would be much higher. $\triangleq$

2. This is due to the fact that criminal offence is related to robbery. Its definition in Criminal Code is: "Whoever caught in the act of theft and with intent to keep the stolen object uses force against a person or threat of direct attack against the life or body...". The literal translation from Serbian is "robbery theft". $\bullet$

3. This occurred if a street name was misspelt or changed in the meantime. $ヒ$

4. Many events occur along the street and on intersections, and police officers cannot determine the street's particular number. $\triangleq$

5. The authorities state that GIS data of the city is currently unavailable. Online research did not produce appropriate data regarding administrative boundaries.

6. There were no data for 2008 and 2013.

7. Dark number in criminology is defined as all crimes not reported to or detected by the police. $ヒ$ 